Review

\title{
Sombric horizon: five decades without evolution
}

\author{
Jaime Antonio de Almeida ${ }^{1}$, Antônio Lunardi Neto ${ }^{2}$, Pablo Vidal-Torrado ${ }^{\text {* }}$
}

${ }^{1}$ State University of Santa Catarina/Agro Veterinary Sciences Center, Av. Luiz de Camões, 2090 - Bairro Conta Dinheiro 88520-000 - Lages, SC - Brazil.

${ }^{2}$ Federal University of Santa Catarina, Campus Curitibanos, Rod. Ulysses Gaboardi, Km 3 - 89520-000 - Curitibanos,

SC - Brazil.

${ }^{3}$ University of São Paulo/ESALQ - Dept. of Soil Science, C.P. 09 - 13418-900 - Piracicaba, SP - Brazil.

*Corresponding author <pvidal@usp.br>

Edited by: Leônidas Carrijo Azevedo Melo

Received March 28, 2014

Accepted July 112014
ABSTRACT: The sombric horizon is a diagnostic subsurface horizon defined in the soil classification system of the United States (Soil Taxonomy) and FAO (WRB), used to classify the soil at different categorical levels. The sombric horizon has a soil color darker than the overlying surface(s) horizon(s), and must show illuvial humus accumulation features, though they are not associated with aluminum (Al), as in the spodic horizon, nor associated with sodium ( $\mathrm{Na}$ ), as in the natric horizon. There are also criteria to distinguish it from buried A horizons. However, since the first references and proposed concept of the sombric horizon in African soils made by Sys and co-workers in the 1960s, and adopted by the Soil Taxonomy edition of 1975, few modifications have been made to its definition. Moreover, the pedogenic process involved in illuvial humus accumulation in these horizons remains inadequately clarified, making the distinction between the sombric and spodic or buried A horizon difficult and unclear. This review reports the historical evolution of the sombric horizon concept, its definition and inconsistencies under different soil classification systems, and the current hypothesis, together with its fragilities, proposed to explain the soil illuvial humus accumulation. Although it is recognized that further research is necessary, alternative criteria are proposed for the definition of the sombric horizon in the Brazilian System of Soil Classification. Keywords: subsurface horizon, illuvial humus accumulation, buried A horizon, soil classification, SiBCS

\section{Introduction}

The first definition of the sombric horizon in Soil Taxonomy (USDA, 1975), and in its later version (Soil Survey Staff, 2014), was originally based on the soil survey of the Congo (currently the Republic of Zaire) in Africa, proposed by Sys et al. (1961). The authors defined the sombric horizon as a horizon with illuvial humus accumulation.

The World Reference Base for Soil Resources (WRB) later introduced a similar definition (FAO, 2014). The central concept of illuvial humus accumulation remained for more than 50 years without being formally contested, due to the few studies conducted on the genesis of the sombric horizon.

The sombric horizon shows similar morphology to other horizons, such as spodic horizons, or some soils with natric horizons or buried A horizon. Little is known about the mechanisms and processes involved in illuvial humus accumulation in the sombric horizon, making its identification and genesis even more unclear.

Since its definition was formally adopted by Soil Taxonomy in 1975, the sombric horizon has been mainly identified from its morphological characteristics, position in the soil profile and lateral continuity in toposequences, and landscapes. Several authors report the occurrence of the sombric horizon in soils; however, in many cases, its characteristics do not allow its definition or there are insufficient analytical data for an accurate identification. Bockheim (2012) analyzed 30 soil profiles with the occurrence of the sombric horizon and observed that only 12 profiles met the requirements es- tablished in Soil Taxonomy and WRB for the classification of the sombric horizon.

In this review we report the historical evolution of the sombric horizon concept, its definitions and inconsistencies in different soil classification systems, and discuss the current hypothesis of formation, as well as uncertainties, proposed to explain the illuvial humus accumulation in the soil. Finally, an alternative criterion for the definition of the sombric horizon for Brazilian conditions is proposed.

\section{Genesis and definition of the sombric horizon}

Kellogg and Davol (1949) apud Frankart (1983, p.50) were the first authors to report the presence of a dark B horizon with greater humus content than the overlying horizons in several Ultisols at 1,800 $\mathrm{m}$ a.s.l. in Rwanda, Central Africa. The authors interpreted the dark B horizon as a buried pre-forested humic horizon. Occurrence of sombric-like horizons was later reported in several countries in Central Africa (Burundi, Uganda and Tanzania) and South America (Frankart, 1983).

In the Kivu region of the Republic of Zaire, Ruhe (1956) described the physical-chemical properties and geomorphologic distribution pattern of sombric-like horizons, concluding that the so-called "subsurface dark soil" was a subsurface horizon where illuvial humus was accumulated. After 1960, most soil scientists from the "National Institute for the Agronomic Study of Belgian Congo - (INEAC)" agreed on the illuvial origin of the sombric horizon. The process that caused illuvial humus, however, remained unknown (Frankart, 1983).

Sys et al. (1961), apud Frankart (1983, p.50), defined sombric horizon as: "Black, dark gray or dark red- 
dish brown illuvial horizon with organic matter accumulation below the B2c (consistence B2) or B2s horizon (structural B2), at the high altitude Kaolisols". Tavernier and Sys (1965), apud Frankart (1983, p.50), defined it as: "Subsurface horizon of $10 \mathrm{~cm}$ or more, at least one unit darker, containing greater organic matter than the overlying horizon". A similar concept to that proposed by Sys et al. (1961) and Tavernier and Sys (1965) apud Frankart (1983, p.50), was incorporated in the first edition of Soil Taxonomy (USDA, 1975), with amendments:

"The sombric horizon is a subsurface horizon of mineral soils formed under free drainage. It contains illuvial humus that is neither associated with $\mathrm{Al}$, as in the spodic horizon, nor dispersed by $\mathrm{Na}$, as is common in the natric horizon. The sombric horizon does not underlie an albic horizon and it is restricted to cool moist soils of the high plateaux and mountains of tropical and subtropical regions. These soils have a low base saturation degree. The sombric horizon has a lower color value or chroma, or both, than the overlying horizon and commonly, but not necessarily, contains a higher humus content than the overlying horizon. It may have formed in an argillic, a cambic or, possibly, an oxic horizon. It is easily confused in the field with a buried A1 horizon."

The same definition was presented in later editions, with small variations, and the 2014 issue (Soil Survey Staff, 2014) shows the following definition of the sombric horizon:

"A sombric (from French: sombre = dark) horizon is a subsurface horizon in mineral soils that was formed under free drainage. It contains illuvial humus that is neither associated with $\mathrm{Al}$, as is the humus in the spodic horizon, nor dispersed by $\mathrm{Na}$, as is common in the natric horizon. Consequently, the sombric horizon does not have the high cation-exchange capacity in its clay that characterizes a spodic horizon and does not have the high base saturation of a natric horizon. It does not underlie an albic horizon. Sombric horizons are thought to be restricted to the cool, moist soils of high plateaux and mountains in tropical or subtropical regions. Because of strong leaching their base saturation is low (less than 50 percent by $\mathrm{NH}_{4} \mathrm{OAc}$ ). The sombric horizon has a lower color value or chroma, or both, than the overlying horizon and commonly contains more organic matter. It may have formed in an argillic, cambic or oxic horizon. If peds are present, the dark colors are more pronounced on surfaces of peds. In the field, a sombric horizon is easily mistaken for a buried A horizon. It can be distinguished from some buried epipedons by lateral tracing. In thin sections, the organic matter of a sombric horizon appears more concentrated on peds and in pores than uniformly dispersed throughout the matrix."

The soil classification system of the World Reference Base for Soil Resources (FAO, 2014) defines the sombric horizon as:

"A sombric horizon (from French: sombre = dark) is a dark-colored subsurface horizon containing illuvial humus that is neither associated with $\mathrm{Al}$ nor dispersed by $\mathrm{Na}$. A sombric horizon consists of a mineral material and: a) has a lower Munsell colour value or chroma than the overlying horizon; b) has a base saturation (by $1 \mathrm{M}$ $\mathrm{NH}_{4} \mathrm{OAc}, \mathrm{pH}$ 7) lower than 50 percent; c) shows evidence of humus accumulation, by a higher soil organic carbon content than the directly overlying horizon, or through illuvial humus on soil aggregate surfaces or in pores visible in thin sections; d) does not underlie a layer with albic material and does not form part of a spodic horizon; and e) has thickness of $15 \mathrm{~cm}$ or more." Field identification: "Sombric horizons are found in dark-colored subsoil, associated with cool and well-drained moist soils of high plateaux and mountains in tropical and subtropical regions. They resemble buried horizons but, in contrast to many of these, sombric horizons more or less follow the shape of the surface". Relationships with some other diagnostics: "Sombric horizons may coincide with argic, cambic, ferralic or nitic horizons. Sombric horizons may resemble melanic and fulvic or buried umbric horizons. Spodic horizons are differentiated from sombric horizons by their much higher CEC of the clay fraction. The humus-illuvial part of natric horizons has a base saturation (by $1 \mathrm{M} \mathrm{NH}_{4} \mathrm{OAc}, \mathrm{pH} 7$ ) of $50 \%$ or more, which separates them from sombric horizons."

These definitions show some differences between the two soil classification systems for the sombric horizon. In Soil Taxonomy, the humus content in the sombric horizon is commonly, but not necessarily, higher than in the overlying horizon. The WRB attest that there should be either evidence of higher humus content in the dark subsurface horizon than in the overlying horizon or the presence of illuvial humus in pores and covering aggregates. Regarding the thickness of the sombric horizon, the $\mathrm{WRB}$ requires a minimum thickness of $15 \mathrm{~cm}$.

Despite these differences, the essence of the definition remains, that is, both require the absence of humus accumulation dispersed by $\mathrm{Na}$ or associated with $\mathrm{Al}$, as in the spodic horizon, which implies illuvial humus accumulation through a differentiated mechanism, not yet clarified.

\section{Horizons similar to the sombric horizon}

There are specific situations in which the occurrence of dark subsurface horizons is typical of certain soil classes and landscapes, as in Spodosols (Spodosols, in SiBCS -the Brazilian System of Soil Classification - Santos et al., 2013). Tropical humid regions of Spodosols are typically associated with hydromorphism in weathered landscapes (Klinge, 1965; Dubroeucq and Volkoff, 1988; Gomes et al., 2007; Coelho et al., 2012; Buurman et al., 2013), generally in sedimentary sandy plains. In temperate climates, spodic dark subsurface horizons occur mainly at the top of mountains, mostly associated with coniferous vegetation, notably in the Northern hemisphere (Lundström et al., 2000b), generally, with high sand contents and little occurrence in clayey soils.

These soils are formed from the podzolization process, which results from the formation of the $\mathrm{B}$ horizon 
with the accumulation of humus, iron (Fe) and/or $\mathrm{Al}_{\text {, }}$ in the form of organometallic compounds (De Conink, 1980). Commonly, spodic darkened subsurface horizons show an overlying eluvial E horizon, lighter-colored than the spodic, resulting from humus loss. The typical soil genetic horizon sequence in Spodosols is $\mathrm{A}, \mathrm{E}$ and $\mathrm{Bh}$ or Bs.

A significant amount of $\mathrm{Na}$ in soils may cause clay and humus dispersion, favoring their accumulation in subsurface horizons, where a columnar structure with a dark top layer may be formed by illuvial humus accumulation (Cunha, 1980). This has been observed in a number of Alfisols (Natric Planosols and certain Haplic Planosols, in SiBCS), solodic soil types, where the formation of a B horizon with a dark top layer may occur.

Dark subsurface horizons may also result from the burial of an A horizon by subsequent depositions, resulting in a buried A horizon. This situation may be observed at the footslope of hillocks, where upland colluvial soil may have been deposited on downslope soils. In many cases, the depositional layer has similar composition to the buried soil, making it difficult to define the buried solely based on field evidences (Ruellan, 1971). On the other hand, the hypothesis of colluvial burial is discarded when the dark horizon shows lateral continuity in several segments of the landscape, such as the upslope and footslope, indicating prevalence of the pedogenetic processes.

Buried soils may also be classified as Paleosols, provided that they were subjected to climate changes, characterizing distinct past landscapes (Ladeira, 2010). In this case, some Paleosols may occur with old darker color at the top of the subsurface horizon

Dark subsurface horizons are also observed in soils that show evidence of anthropogenic activities, with severe degradation and transformation of humus in the top soil layers, caused by intense soil use, which makes the subsurface layer of the former thicker A horizon darker than the degraded surface layer. In the U.S. soil classification system, the agric horizon addresses this question, occurring directly under the Ap horizon, showing criteria of color and thickness for its definition. However, the SiBCS does not report the agric horizon.

Widespread in Brazilian Amazonia, there are many scattered areas of anthropogenic soils called: "Indian Black Earth", whose surface horizons are darker and more fertile than the lighter-colored adjacent soilscapes (Kern et al., 2003). In some cases these dark horizons occur below lighter-colored horizons, which may indicate burial by alluvial or colluvial material, as well as reforestation in certain areas that produce lighter-colored humus at the top soil surface with soil composition different from that caused by former anthropogenic activities. When these dark horizons occur in the subsurface soil, they may also show morphology similar to sombric horizons, though with differences due to fertility.

The definition of that horizon in FAO (2014), called "a pretic horizon" (from Portuguese: preto = black) is: "a mineral surface horizon that results from human activities including the addition of charcoal. It is characterized by its dark color, the presence of artefacts (ceramic fragments, lithic instruments, bone or shell tools etc.) and high contents of organic carbon, phosphorus, calcium, magnesium and micronutrients (mainly zinc and manganese), usually contrasting with natural soils in the surrounding area. It typically contains visible remnants of charcoal. Pretic horizons are, for example, widespread in the Amazon Basin, where they are the result of preColumbian activities and have persisted over many centuries despite the prevailing humid tropical conditions and high organic matter mineralization rates. These soils with a pretic horizon are known as 'Indian Black Earth' or 'Amazonian Dark Earths'. They generally have high organic carbon stocks. Many of them are dominated by low-activity clays" (FAO, 2014).

\section{Distinction between sombric and spodic horizons}

There are great differences between the concepts of sombric and spodic horizons. In sombric horizons, the illuvial humus cannot be Al-saturated, while in spodic horizons, illuvial humus is commonly associated with $\mathrm{Al}$, with or without Fe and other cations (De Conink, 1980; Lundström et al., 2000a), due to migration and accumulation of illuvial humus complexed with metals. However, spodic horizons are not necessarily formed by vertical mobilizing of organic matter. In hydromorphic Spodosols, spodic horizons can be formed by lateral movement of illuvial humus, favoured by the high macro and mesoporosity and dinamics of water-table fluctuations (Buurman et al., 2013).

Generally, in most horizons characterized as sombric, there are no analytical data to corroborate the absence of $\mathrm{Al}$ associated with humus, because its identification is made based mainly on soil morphology. In many cases, the presence of high exchangeable Al extracted with the $1 \mathrm{M} \mathrm{KCl}$ solution is used as a parameter to discard the hypothesis of the sombric horizon (Bockheim, 2012); however, this is not a safe criterion, once $\mathrm{Al}$ can derive from dissolution of mineral fraction.

Illuvial humus in Spodosols commonly results in the formation of an $\mathrm{E}$ horizon, which can be an albic horizon, located above the spodic B horizon. Usually these $\mathrm{E}$ albic horizons are discontinuous, with irregular topography in relation to the soil surface. In the sombric horizon, on the other hand, the eluvial E horizon cannot be present. One may ask how can illuvial humus accumulate in the $\mathrm{B}$ horizon if no eluviation features are to be observed in the overlying horizons? This question is still unanswered and very few micromorphological studies have been conducted with this objective.

The main requirements used to differentiate spodic from sombric horizons are:

- association (spodic) or non-association (sombric) of the illuvial humus with $\mathrm{Al}_{i}$

- presence or absence of an E horizon overlying the dark subsurface horizon: commonly present in the spodic, but necessarily absent in the sombric horizon; 
- differences in the association pattern of illuvial humus with the dark subsurface peds, derived from micromorphological analyses: in the sombric horizons, cutans (organs) must be preferentially located onto ped surfaces, rather than inside peds, and in the spodic horizon, it is disseminated by all the soil matrix; and

- natural drainage: the spodic horizon is commonly associated (mainly in Brazilian Spodosols) with poorly to moderately drained conditions, and soils with sombric horizons must always be formed in free drainage conditions.

Nevertheless, in many situations the properties and morphological features of the soil do not allow for a clear identification of one or another horizon, because both processes are not clearly understood. New approaches and studies are necessary for distinguishing the sombric from the spodic horizons.

\section{Peculiarities of the sombric horizon}

Criteria cited by Paramananthan and Eswaran (1980) for soils belonging to the large group of Sombriorthox, include the formation of dark depositions - coatings, according to Bullock et al. (1985) and organs, according to Brewer (1976) - on ped surfaces of sombric horizons, with or without penetrations. Eswaran and Tavernier (1980) detailed the morphology of these depositions and highlighted that the darkening of the B horizon starts in the periphery of the peds and increases its intensity as it moves inwards, until the entire matrix becomes darkened. According to these authors, this sequence may be followed across the landscape, where the initial stage of darkening occurs in downslope, and increases its intensity in flat areas, showing a pedogenic nature rather than deposition.

Another question in the characterization of the sombric horizon is the variation of its vertical positions in the soil profile. In most soils studied in Central Africa (Sys et al., 1961; Frankart et al., 1974; Frankart, 1983; Sehgal and Sys, 1970), the sombric horizon is found in some B subhorizons, while in other studies, such as Faivre (1990) in Colombia, Caner et al. (2003) in India and Oenning (2001), Almeida et al. (2009), Botelho (2011) and Lunardi Neto (2012) in Brazil, the sombric horizon coincides with $\mathrm{AB}$ and/or BA (lower part of $\mathrm{A}$ and top part of $\mathrm{B}$ horizons) transitional genetic horizons.

The position of the sombric horizon may coincide with the horizon of clay accumulation, such as in Ultisols under the U.S. soil classification system (Soil Survey Staff, 2014), where the sombric horizon may occur in the argillic horizon (Sombriudults) or in the kandic horizon (Sombric Kandiudults). On the other hand, no evidence of clay illuviation may occur in the Sombriudox, Sombriustox and Sombriperox great groups. In soil profiles studied by Faivre (1990) in Colombia and Ultisols (Red Argisols, in SiBCS) studied by Almeida et al. (2009) in Brazil, there was evidence that illuvial humus was associated with the argilluviation process in the dark subsurface horizon, coinciding with the top B horizon.
In the soil profiles studied by Caner et al. (2003) in India, the dark subsurface horizon coincided with the lower part of the A horizon, but at the same time, it showed humus significantly saturated with Al. The authors argued that these soils, previously classified as Oxisols and Ultisols, should be classified now as Andisols (there are currently no Andisols in SiBCS), because, although they are allophane-free, they show andic properties, due to the richness of organometallic complexes in the dark subsurface horizons. These results show that the absence of $\mathrm{Al}$ associated with illuvial humus in the sombric horizon does not seem a suitable criterion for the definition of this horizon.

\section{The sombric horizon in Brazil}

In most soils, darker horizons occur in surface horizons, due to the greater humus accumulation at the soil surface and the high saturation of humus with metals, such as $\mathrm{Ca}, \mathrm{Mg}$ and $\mathrm{Al}$, which make them insoluble and stable. In the case of acid soils, $\mathrm{Al}$ is generally the saturating metal, for example in the umbric epipedon (humic and prominent A horizons, in SiBCS). In the case of mollic epipedon (chernozemic A horizon, in SiBCS), the humus stability is attributed mainly to $\mathrm{Ca}$ and/or $\mathrm{Mg}$ saturation.

In several soils in the state of Santa Catarina, Brazil, under Rain Forest and Araucaria Forest vegetation, mainly in Ultisols derived from sandstones and pellitic rocks (Figure 1A) (Red Argisols, in SiBCS), located at lower altitudes (Almeida et al., 2009), and in Ultisols (Grayish-Brown Argisols, in SiBCS) derived from pellitic rocks (Figure 1B) occurring at higher elevations in Santa Catarina (Oenning, 2001), the presence of dark subsurface horizons is common.

Soils with sombric-like horizons are also found in many regions of the state of Rio Grande do Sul, Brazil, mainly in Ultisols (Grayish-Brown Argisols, in SiBCS). They have developed in different geological substrates: a) granodiorites (Figure 2A), in Canguçu (Botelho, 2011); b) pellitic, in Rosário do Sul (Figure 2B), São João do Polêsine (Figure 2D) (Oliveira, 2012) and Cacequi (SNLCS, 1980); and c) rhyolite-dacite volcanics in the municipality of Arvorezinha (Figure 2E). These sombric-like horizons are sometimes observed on the surface of migmatites in Alfisols (Luvisols, in SiBCS), such as in the municipalities of Bagé (Figure 2C) (Lunardi Neto, 2012), or Canguçu (Botelho, 2011). In these landscapes, these soils show darkening features at the top layer of the B horizon, raising questions about the pedogenetic processes that originated them.

In the states of Santa Catarina and in Rio Grande do Sul, the dark subsurface horizons coincide with the $\mathrm{AB}$ and/or the $\mathrm{BA}$ transitional genetic horizon, and its morphologies suggesting that they are possibly sombric horizons, as defined in Soil Taxonomy (Soil Survey Staff, 2014) or the World Reference Base (FAO, 2014). Almeida et al. (2009) reported the occurrence of sombric horizon in Ultisols (Red Argisols, in SiBCS) derived from siltstone interlayered with sandstone, in the southern region of Santa Catarina (Figure 1A), and Botelho (2011) 
reported its occurrence in Ultisols (Grayish-Brown Argisols, in SiBCS) derived from intrusive and metamorphic magmatic rocks in the Crystalline Shield of the state of Rio Grande do Sul (Figure 1B).

In other regions of Brazil, there are reports of sombric horizons in Inceptisols (Cambisols, in SiBCS) in the southern region of the state of Minas Gerais, in Oxisols (Latosols, in SiBCS) in the state of Paraná (Volkoff and Cerri, 1987), in Oxisols on Chapada Diamantina, in the state of Minas Gerais (Schaefer et al., 2002), and in Oxisols (Kandic) (Nitosols, in SiBCS) in the municipality of Botucatu, in the state of São Paulo (Miklós, 1999).

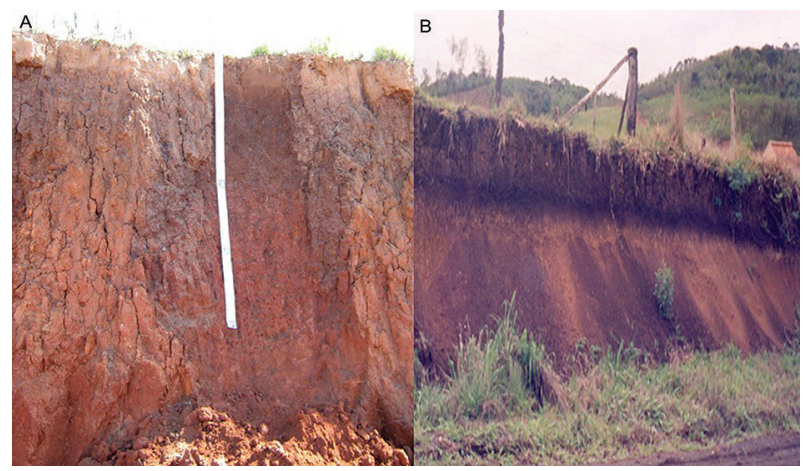

Figure 1 - Soil profiles of Ultisols (Red Argisol (A) and Grayish-Brown Argisol (B), in SiBCS) located near the municipalities of Içara and Santa Terezinha, respectively, in the state of Santa Catarina, with darkening evidences in the subsurface horizons. Pictures: Jaime Antonio de Almeida and Sérgio Hideiti Shimizu, respectively.

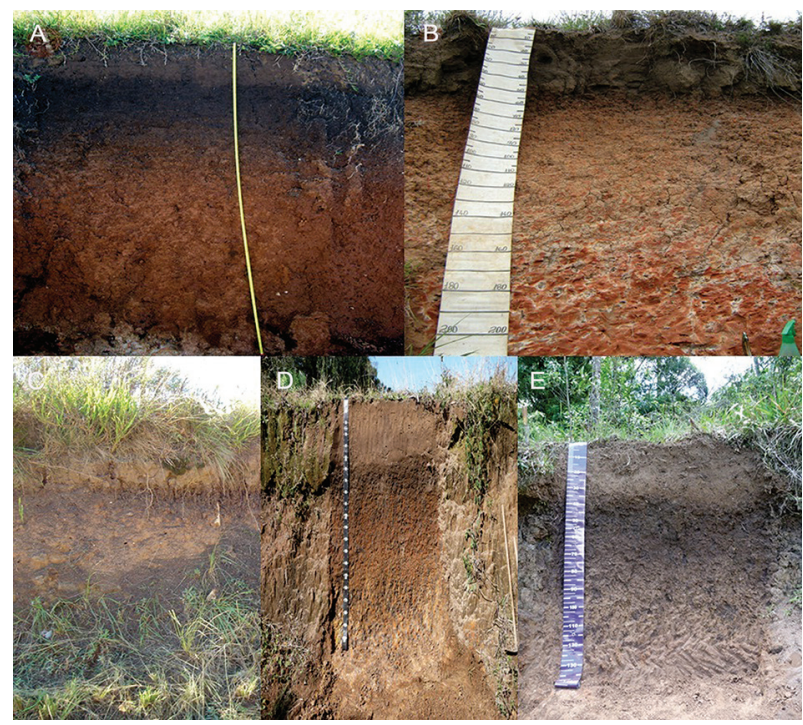

Figure 2 - Soil profiles of Ultisols (Grayish-Brown Argisols, in SiBCS), with dark top of $B$ horizon, in the municipalities of Canguçu (A), Rosário do Sul (B), São João do Polêsine (D) and Arvorezinha (E), and in an Alfisol (Luvisol, in SiBCS) (C) in the municipalities of Bagé, all in the state of Rio Grande do Sul, Brazil. Pictures: Márcio Botelho (A) and Jaime Antonio de Almeida (B, C, D and E), respectively.

\section{Hypothesis for the sombric horizon formation}

Frankart (1983) presents two hypotheses for the sombric horizon genesis in African soils: a) they are relicts of buried A horizon (De Craene and Laruelle, 1955; Riquier, 1966; Escobedo, 1980, apud Frankart, 1983, p.57), and b) they result from illuvial humus accumulation (Sys et al., 1961; USDA, 1975), without an explanation of how the process occurs.

Mutwewingabo (1989) deduced that Kaolisols (Oxisols, in Soil Taxonomy; Latosols, in SiBCS) studied in Rwanda, Africa, in regions where the sombric horizon was originally described, showed polygenetic characteristics, and concluded that the many dark subsurface horizons previously described would be old buried A horizons. However, in the region of Butare, the author concluded that these soils could not have been formed by current pedogenetic processes, without discarding the hypothesis that dark subsurface horizons are sombric horizons.

Faivre (1990) studied several soils with sombric-like horizons in the Andes Mountains and hypothesized that humus was accumulated in these soils by non-dissociated clay-humic material transport, which brings a different viewpoint to any elucidation of the formation process of the sombric horizon in certain soils. Almeida et al. (2009) also highlighted this possibility in Ultisols (Red Argisols, in SiBCS) of Santa Catarina State. Van Wambecke (1992) hypothesized that certain dark subsurface horizons from plateaux in Africa may be remnants of a colder climate, a hypothesis that was later tested and confirmed by Caner et al. (2003) in plateaux in India. Miklós (1999) suggested the possibility that dark subsurface horizons in soils of toposequence in São Paulo State could be buried paleohorizons covered by lighter-colored material, transported upwards by the soil fauna, namely termites. In this respect, Schaefer et al. (2002) also identified sombric horizons affected by pedoturbation rather than colluviation. Marques et al. (2011) identified coal lines at depth in some Oxisols (Latosols, in SiBCS), in the states of São Paulo and Minas Gerais, evidencing the transport of material from lower to upper horizons by the soil fauna.

Oenning (2001) attributed to an incipient podzolization process the formation of dark subsurface horizons in Ultisols (Grayish-Brown Argisols, in SiBCS) in the states of Santa Catarina and Rio Grande do Sul, based mainly on the analysis of carbon fractioning of humic substances, selective extractions and micromorphological analyses. Caner et al. (2003) studied soil profiles from plateaux in southern India and compared two soils with a thick dark surface horizon with other soils containing the subsurface of sombric-like horizons that showed a basis of thick A horizon with darker color than the upper surface. In an extensive study, the authors quantified the carbon isotopes ${ }^{12} \mathrm{C}$ and ${ }^{13} \mathrm{C}$ and dated ${ }^{14} \mathrm{C}$ in several horizons of all soils and evaluated differences in types of predominant humic compounds in each case.

Their results show that in soils with dark subsurface horizons, the darker color was related to the presence of condensed humic acids of Kumada type A (me- 
lanic) (Kumada, 1987). These horizons showed higher average residence time of humus, showing $\Delta^{13} \mathrm{C}$ (delta ${ }^{13} \mathrm{C}$ ) indicative of a predominance of $\mathrm{C}_{4}$ plants (grass), while on the surface, humus was more recent, derived mainly from $\mathrm{C}_{3}$ plants (forest), containing less condensed humic acids with a lighter color.

Caner et al. (2003) concluded that the darker subsurface portion of the soil was composed by relics of thick accumulation of humus occurring in the surface portion of the soil during a drier period, when grass vegetation cover predominated, which was later replaced by forests in more humid climate, promoting a reduction of the humus dark color in the surface horizon. The results obtained by Caner et al. (2003) point to an alternative hypothesis for the genesis of sombric-like horizons, where illuvial humus may not be involved, confirming the hypothesis that these horizons are old A horizons. They may simply be results of changes in the vegetation composition caused by climatic changes.

Bautista-Cruz et al. (2005) studied chronosequence in soils from areas originally covered by mountain mesophilic forest in Mexico and concluded that vegetation and time played an important role in horizon differentiation and soil properties. Pedological heterogeneity increased with the forest age. In the initial succession stages, thin A horizons were formed until the horizons became more developed, leading to diagnostic horizons such as folistic, and sombric in the last succession stages.

Almeida et al. (2009) consider the hypothesis of an incipient process of podzolization in Ultisols (Red Argisols, in SiBCS) with dark subsurface horizons similar to the sombric horizon in the municipality of Içara, in the state of Santa Catarina, due to accumulation of $\mathrm{Al}$ associated with humus in the subsurface, indicated by the maximum $\mathrm{Al}$ contents extracted with ammonium oxalate, copper chlorite and $\mathrm{Na}$ pyrophosphate in these horizons. However, due to the absence of an E horizon, Almeida et al. (2009) proposed the hypothesis of humic-argilluviation in the formation of these horizons, given that the maximum values for the fine clay/total clay ratio coincided with the dark subsurface horizons, and not with the horizons with the maximum accumulation of soil clay, located below the dark subsurface horizon. These results led to the conclusion that the illuvial humus accumulation had occurred after the formation of argillic horizon (textural B horizon, according to SiBCS). The soil used in this study was located in a region of low altitude where the sombric horizon is not commonly reported.

Velasco-Molina et al. (2010) credited the genesis of dark subsurface horizons of Ultisols (Red Argisols, in SiBCS), from the municipality of Içara, in the state of Santa Catarina, to changes of soil use, to differences of short distances in the illuvial humus accumulation and to forest burnings, based on studies on chemical fractioning and quantification of carbon fractioning of the humus.

More recently, Botelho (2011) conducted studies on Ultisols (Grayish-Brown Argisols, in SiBCS), including Entisols and Alfisols (Regolitic Neosols and Luvisols, respectively, in SiBCS) in the municipality of Pelotas, in the state of Rio Grande do Sul, Brazil, and suggested the existence of paleohorizons in several soils, with dark subsurface horizons formed from an original vegetation different from the current vegetation cover, based mainly on quantitative results of carbon isotopes and carbon fractioning of the humus. These results are in accordance with Caner et al. (2003).

Lunardi Neto (2012) studied an Ultisol (Red Argisol, in SiBCS) with dark subsurface horizons in the state of Santa Catarina using carbon isotope analysis. The author did not find enough evidences to conclude that these horizons had originated from a different vegetation cover. Moreover, the author did not find evidences of the podzolization process in these soils, so it was concluded that humic-argilluviation seems to be a process for the formation of these horizons, in line with Almeida et al. (2009).

As reported, few studies have been conducted on sombric horizons, and only recently, some Brazilian authors, namely Miklós (1999), Oenning (2001), Almeida et al. (2009), Botelho (2011) and Lunardi Neto (2012), have investigated the genesis of these horizons. Bockheim (2012) concluded that only twelve out of thirty soil profiles reported in the literature as sombric horizons were in accordance with the definition of sombric horizon by Soil Taxonomy and WRB systems. In the thirty soil profiles studied, however, the author did not considere sombric horizons those where the requirement of an increase in carbon content was not satisfied. We understand that this is not an essential requirement in Soil Taxonomy. The phrase "commonly contains more organic matter", in Soil Taxonomy, does not mean essential requirement when all other requirements are satisfied.

\section{Final remarks}

The concept of the sombric horizon holds practically the same uncertainties since it was created about five decades ago, without significant changes. Among the scientific studies carried out to investigate its genesis, few soils fully meet the requirements established by Soil Taxonomy (Soil Survey Staff, 2014), or more recently by WRB (FAO, 2014). The absence of $\mathrm{Al}$ associated with humus, a feature essential to the characterization of the sombric horizon, seems only an attempt to differentiate them from spodic horizons, rather than a criterion with a solid scientific basis, given that the mechanisms involved in illuvial humus accumulation in these horizons are still unknown.

The current knowledge on the genesis of the sombric horizon points to the following consensus among researchers about its definition:

1 - It is a dark subsurface horizon that should not be preceded by an E illuvial horizon, albic or not, in order to differentiate it from an spodic horizon;

2 - It should not show evidence of burial processes, that is, it should be differentiated from an old buried A horizon; 
3 - It should have a darker color in the dry and/or moist samples than the overlying horizon;

4 - It should have a higher carbon content than the overlying horizon or shows macro or micromorphological evidence that indicate illuvial accumulation, such as cutans depositions on ped surfaces or in pores, rather than being uniformly distributed in the soil matrix;

5 - It should be low in base saturation, given that high contents of exchangeable bases may reduce the humus solubility, hindering, therefore, vertical mobilization and illuvial humus accumulation;

6 - It should not have $\mathrm{Al}$ associated with illuvial humus to differentiate it from the spodic horizon;

7 - It should not be associated to landscapes with high $\mathrm{Na}$ contents due to its dispersive action in humic substances, thereby facilitating its transport downward in the profile;

8 - It should have a minimum thickness, which is a criterion required for the definition of any horizon;

9 - It should not have a characteristic derived from anthropogenic activities in the soil surface that promotes its whitening, to differentiate it from an agric horizon (Soil Taxonomy).

Regarding the requirements that the sombric horizon need to be formed by illuvial humus accumulation, as present by its genesis definition, the following considerations should be:

1 - Although in many cases illuvial processes are proved using micromorphology and chemical analyses, recent studies, such as Caner et al. (2003), clearly show that the dark subsurface horizons may result from changes in the vegetation composition caused by climatic changes. Therefore, they are not necessarily from illuvial origin, even though they are darker and have higher carbon content than the underlying horizons (humus is not accumulated by illuviation and it is not a typical buried $\mathrm{A}$ horizon);

2 - The absence of macro and/or micromorphological characteristics, indicative of illuviation in the horizon, do not necessarily imply the exclusion of the sombric horizon, given that these features may have been destroyed by soil disturbances.

The requirement that illuvial humus should not be associated with $\mathrm{Al}$ also deserves questioning. Where dark subsurface horizons have been formed from old vegetation different from the current vegetation cover, induced by climatic changes, they may contain humus associated with $\mathrm{Al}$, without implying that humus had been accumulated like organometallic compounds; but it is not necessarily a spodic horizon. Furthermore, if we consider the humic- argilluviation hypothesis, we cannot overlook the fact that humus transported with clay must be $\mathrm{Al}$ saturated.

To avoid the general requirement that a sombric horizon "should not contain $\mathrm{Al}$ associated to illuvial humus", Bockheim (2012) suggested using $\mathrm{Al}$ and Fe extracted by ammonium oxalate $(\mathrm{Al}+1 / 2 \mathrm{Fe})$ ox as a criterion for the differentiation of the spodic from the sombric horizon, proposing that $(\mathrm{Al}+1 / 2 \mathrm{Fe})_{\mathrm{ox}}$ should be lower than $0.5 \%$ in the sombric, given that this value must be equal or higher in the spodic horizon according to the Soil Taxonomy system. However, this criterion, besides being empirical, has been questioned as a valid requirement for the definition of a spodic horizon (Coelho et al., 2010). We believe that this is not a valid criterion. As discussed earlier, high levels of $\mathrm{Al}$ can be present in the dark subsurface horizons when they are relicts of past vegetation, or when we consider the humic-argilluviation hypothesis. In these situations, high levels of Al-oxalate must be found, but not necessarily associated with the podzolization process. We need to decide, however, if these two situations should be included in the sombric horizon definition.

The requirement that sombric horizon must show low base saturation is found in most studies on soil profiles from several regions in the world. However, many profiles of high CEC Alfisols (Luvisols, in SiBCS) in southern Brazil show a darker top of the $\mathrm{B}$ horizon with similar sombric features (Figure 2B). Further studies are required to clarify the mechanisms/processes responsible for the darkening of these soils. Therefore, although there is relative consensus to exclude from the definition of sombric horizon the cases of the buried A horizon, the spodic horizon or the natric horizon with humus accumulation, as well as the cases where the agric horizons rests on a darker subsurface horizon, it is suggested that in other specific situations, the sombric horizon should be recognized, regardless of its illuvial origin or not, and if the $\mathrm{Al}$ was associated with the illuvial humus or not, excluding the sombric horizon only where the four situations above are identified. The presence of subsurface horizons darker than the overlying horizons is a fact observed in many soils, and this morphology cannot be ignored, since it is a consequence of pedogenic processes, not yet fully explained.

The following criteria for the definition of the sombric horizon in the Brazilian Soil Classification System are proposed:

"It is a subsurface horizon, transitional or principal (lower part of $\mathrm{A}, \mathrm{AB}, \mathrm{BA}$ or $\mathrm{B}$ ), found in mineral soils of free drainage and unsaturated, where there is evidence of humus accumulation, by illuviation process or not, that does not meet the requirements for the definition of the spodic horizon, does not meet the features that clearly characterize a buried A horizon, nor is resting below an agric horizon, does not have $\mathrm{Na}$ accumulation, as defined in Soil Taxonomy (Soil Survey Staff, 2014), and that meets all of the following criteria:

a) Presents $10 \mathrm{~cm}$ or more of thickness; 
b) Does not have an E illuvial horizon in its upper limit;

c) Does not meet the characteristics required for the definition of a spodic horizon;

d) Shows lateral continuity in several segments of the landscape, evidencing its pedogenetic origin and discarding a buried horizon;

e) Must show values and/or chromas, in the dry and/or humid samples, lower than the overlying horizon;

f) Should have base saturation lower than $50 \%$ (dystrophic, as diagnostic attribute, in SiBCS);

g.1) Should have evidence of humus accumulation, either from cutans preferably deposited on ped surfaces or pores, rather than uniformly disseminated in the matrix, or have greater organic carbon content in relation to the horizon immediately overlying, or

g.2) Where the horizon does not meet the previous criteria, evidence must be shown of ancient vegetation different from the current vegetation, evaluated in a place not affected by recent anthropic activity.

A recent proposal was presented for an update of SiBCS for the adoption of "sombric character, diagnostic attribute" to allow for the discrimination and classification of soils that show characteristics of sombric-like horizons in the system, with prediction for the discrimination of these soils in the fourth category level (Example: sombric Dystrophic Red Argisols, in Brazilian System Soil Classification - SiBCS). This proposal was incorporated in the third edition of SiBCS (Santos et al., 2013). It is a tentative definition subject to validation by users. However, the mechanisms and processes involved in the identification of the genesis of the sombric horizons (or sombric characteristic) remain inadequately elucidated scientifically, giving rise, therefore, to uncertainties regarding definitions in the several soil taxonomic classification systems.

\section{References}

Almeida, J.A.; Cararo, D.C.; Uberti, A.A.A. 2009. Genesis of the sombric horizon in Ultisols (Red Argisols) in southern Santa Catarina, Brazil. Revista Brasileira de Ciência do Solo 33: 405-416.

Bautista-Cruz, A.; Gutiérrez-Castorena, M. Del C.; CastilloSánchez, R.F. Del; Etchevers Barra, J.D. 2005. Soil chronosequence and its classification in an area originally occupied by mountain cloud forest. Terra Latinoamericana 23: 147-157 (in Spanish, with abstract in English).

Bockheim, J.G. 2012. Revisiting the definitions of the sombric horizon in soil taxonomy and world reference base for soil resources. Geoderma 170: 127-135.

Botelho, M.R. 2011. Genesis of dark subsurface horizons of soils in area of Pelotas Batholith, RS. Available at: http://www2.ufpel.edu. br/tede/tde_arquivos/14/TDE-2012-08-06T101533Z-1086/Publico/ Tese_Marcio_Ramos_Botelho.pdf [Accessed Mar 20, 2014].
Buurman, P.; Vidal-Torrado, P.; Martins, V.M. 2013. The podzol hydrosequence of Itaguaré (São Paulo, Brazil). 1. Geomorphology and interpretation of profile morphology. Soil Science Society of America Journal 77: 1294-1306.

Brewer, R. 1976. Fabric and Mineral Analysis of Soil. R. E. Krieger, New York, NY, USA.

Bullock, P.; Fedoroff, N.; Jongerius, A.; Stoops, G.; Tursina, T.; Babel, U. 1985. Handbook for Soil Thin Section Description. Waine Research Publications, Wolwerhampton, UK.

Caner, L.; Toutain, F.; Bourgeon, G.; Herbillon, A.J. 2003. Occurrence of sombric-like subsurface A horizons in some andic soils of the Nilgiri Hills (Southern India) and their palaeoecological significance. Geoderma 117: 251-265.

Coelho, M.R.; Vidal-Torrado, P.; Otero, X.L.P.; Martins, V.M.; Macias, F. 2010. Chemistry and genesis of soils developed under restinga vegetation in São Paulo state, Brazil. Revista Brasileira de Ciência do Solo 34: 1951-1964 (in Portuguese, with abstract in English).

Coelho, M.R.; Martins, V.M.; Otero, X.L.P.; Macias, F.; Gomes, F.H.; Cooper, M.; Vidal-Torrado, P. 2012. Micromorphology of spodic horizons of the restinga region of São Paulo state. Revista Brasileira de Ciência do Solo 36: 1380-1394 (in Portuguese, with abstract in English).

Dubroeucq, C.; Volkoff, B. 1988. Evolution of the Sandy soil mantle with giant Podzols of Amazonia (upper Rio Negro basin). Cahiers ORSTOM. Série Pédologie 24: 191-214 (in French, with abstract in English).

De Conink, A. 1980. Major mechanisms in formation of spodic horizons. Geoderma 24: 101-128.

De Craene, A.; Laruelle, J. 1955. Genesis and change in tropical and equatorial Oxisols. field observations related with microscopic observations $=$ Genèse et altération des Latosols équatoriaux et tropicaux humides. Les observations sur le terrain en relation avec les observations microscopiques. Bulletin Agricole du Congo Belge 46: 1113-1243 (in French).

Cunha, N.G. 1980. Considerations on soils of the wetland Mato Grosso state, Nhecolândia sub-region = Considerações sobre os solos da sub-região da Nhecolândia, Pantanal Mato-grossense. Embrapa, Corumbá, MT, Brazil (in Portuguese).

Eswaran, H.; Tavernier, R. 1980. Classification and genesis of Oxisols. p. 427-442. In: Theng, B.K.G., ed. Soils with variable charge. Lower Hutt, New Zealand Society of Soil Science, New Zealand.

Faivre, P. 1990. The sombric horizon: an 'incipient' organicargillic horizon; the example of soils of the intra-Andean region of Colombia (South America) = L'Horizon sombrique: une ebauche d'horizon organo-argilique; exemple des sols de la region intrandine de Colombie (Amérique du Sud). Pédologie 40: 273-297 (in French, with abstract in English).

Food and Agriculture Organization [FAO]. 2014. World Reference Base for Soil Resources 2014: International Soil Classification System for Naming Soils and Creating Legends for Soil Maps. FAO, Rome, Italy. (World Soil Resources Reports, 106).

Frankart, R. 1983. The soils with sombric horizons in Rwanda and Burundi. p. 48-64. In: Beinroth, F.H.; Neel, H.; Eswaran, H. eds. Proceedings of the Fourth International Soil Classification Workshop, Rwanda, 1981 - Part I: Papers. ABOS-AGCD, Brussels. 
Frankart, R.; Neel, H.; Sottiaux, G. 1974. The humus-rich soil of the highlands of Rwanda and Burundi: changes in human action $=$ Les sols humifères des regions d'altitude du Rwanda et du Burundi: évolutions sous l'action anthropique. Pédologie 24: 164-177 (in French).

Gomes, F.H.; Vidal-Torrado, P.; Macías, F; Gherardi, B.; Perez, J.L.O. 2007. Soils under restinga vegetation on the Cardoso Island (SP). I. Characterization and classification. Revista Brasileira de Ciência do Solo 31: 1563-1580 (in Portuguese, with abstract in English).

Kellogg, C.E.; Davol, F.D. 1949. An Exploratory Study of Soil Groups in the Belgian Congo. National Institute for Agronomy in Belgian Congo, Brussels, Belgium (Series Science, 46).

Kern, D.C.; D'Aquino, G.; Rodrigues, T.E.; Frazão, F.J.L.; Sombroek, W.; Myers, T.P.; Neves, E.G. 2003. Distribution of Amazonian Dark Earths in the Brazilian Amazon. p. 51-75. In: Lehmann, J.; Kern, D.C.; Glaser, B.; Woods, W.I., eds. Amazonian Dark Earths: origin, properties, management. Kluwer Academic, Dordrecht, Netherlands.

Klinge, H. 1965. Podzol soils in the Amazon basin. Journal of Soil Science 16: 95-103

Kumada, K. 1987. Chemistry of Soil Organic Matter. Japan Scientific Societies Press, Tokyo, Japan. (Developments in Soil Science, 17).

Ladeira, F.S.B. 2010. Soils of the past: origin and identity. Revista Brasileira de Ciência do Solo 34: 1773-1786 (in Portuguese, with abstract in English).

Lunardi Neto, A. 2012. Genesis of the dark subsurface horizons in Ultisols from Santa Catarina state and in Luvisol from the plains of Rio Grande do Sul. Available at: http://manejodosolo. cav.udesc.br/www17/main_2.php?conexao $=84481 \mathrm{~d} 007 \mathrm{ba} 2 \mathrm{~d} 68 \mathrm{a}$ 5bd1251f3f1d1229\&zona = 38 [Accessed Mar 20, 2014].

Lundström, U.S. van; Breemen, N. van; Bain, D.C. 2000a. The podzolization process: a review. Geoderma 94: 91-107.

Lundström, U.S. van; Breemen, N. van; Bain, D.C.; Hees, P.A.W. van; Giesler, R.; Gustafsson, J.P.; Ilvesniemi, H.; Karltun, E.; Melkerud, P.A.; Olsson, M.; Riise, G.; Wahlberg, O.; Bergelin, A.; Bishop, K.; Finlay, R.; Jongmans, A.G.; Magnusson, T.; Mannerkoski, H.; Nordgren, A.; Nyberg, L.; Starr, M.; Tau Strand, L. 2000b. Advances in understanding the podzolization process resulting from a multidisciplinary study of three coniferous forest soils in the Nordic Countries. Geoderma 94: 335-353.

Marques, F.A.; Calegari, M.R.; Vidal-Torrado, P.; Buurman, P. 2011. Relationship between soil oxidizable carbon and physical, chemical and mineralogical properties of umbric ferralsols. Revista Brasileira de Ciência do Solo 35: 25-40.

Miklós, A.A.W. 1999. Stone-lines and oxic horizons: biogenetic organizations - soil fauna. In: Abstracts, Symposium: Slope Processes that Produce Stone-lines. Regional Conference on Geomorphology. Brazilian Geomorphological Union, RJ, Brazil.

Mutwewingabo, B. 1989. Genesis, characteristics and management constraints of sombric acidic deep horizon in Rwanda highland $=$ Genèse, caractéristiques et contraintes dês sols acides à horizon sombre de profondeur de la région de haute altitude du Rwanda. p. 353-385. In: Soiltrop 89. Editions ORSTOM, Paris, France. (in French).

Oenning, I. 2001. Genesis and classification of clayey soil with darkness B horizon from south of Brazil. Available at:http:// alexandria.cpd.ufv.br:8000/teses/solos\%20e\%20nutricao\%20 de\%20plantas/2001/155505f.pdf [Accessed Mar 20, 2014].
Oliveira, R.B. 2012. Identification of the boundary between soil and saprolite in Argissolos Bruno-Acinzentados derivatived from sedimentary rocks. Available at: http://w3.ufsm.br/ ppgcs/disserta\%E7\%F5es\%20e\%20teses/Disserta\%E7\%E3o\%20 Rodrigo\%20B\%20de\%20Oliveira.pdf [Accessed Mar 20, 2014].

Paramananthan, S.; Eswaran, H. 1980. Morphological properties of Oxisols. p. 35-43. In: Theng, B.K.G., ed. Soil with variable charge. New Zealand Society of Soil Science, Lower Rutt, New Zealand.

Riquier, J. 1966. Organic matter in laterite soils = La matière organique dans les sols ferrallitiques. Cahiers ORSTOM, Série Pédologie 4: 33-37 (in French).

Ruellan, A. 1971. The history of soils: some problems of definition and interpretation. p. 3-13. In: Yaalon, D.H., ed. Paleopedology: origin, nature and dating of paleosols. Israel University Press, Jerusalem, Israel.

Ruhe, R.V. 1956. Landscape Evolution in the High Ituri, Belgian Congo. National Institute for Agronomy in Belgian Congo. Brussels, Belgium. (Series Science, 66).

Santos, H.G.; Jacomine, P.K.T.; Anjos, L.H.C.; Oliveira, V.A.; Lumbreras, J.F.; Coelho, M.R.; Almeida, J.A.; Cunha, T.J.F.; Oliveira, J.B. 2013. Brazilian System of Soil Classification $=$ Sistema Brasileiro de Classificação de Solos. 3ed. Embrapa. Brasília, DF, Brazil (in Portuguese).

Schaefer, C.E.R.; Ker, J.C.; Gilkes, R.J.; Campos, J.C.; Costa, L.M.; Saadi, A. 2002. Pedogenesis on the uplands of the Diamantina Plateaux, Minas Gerais, Brazil: a chemical and micropedologic study. Geoderma 107: 243-269.

Sehgal, J.L; Sys, C. 1970. The soils of Punjab (India). Pédologie 20: 244-267.

Sys, C.; Wambecke, A. van; Frankart, R.; Gilson, P.; Jongen, P.; Pécrot, A.; Berce, J.M.; Jamagne, M. 1961. Soil Cartography in Congo: Principles and Methods = La Cartographie des Sols au Congo: ses Principes et ses Méthodes. National Institute for Agronomy in Belgian Congo. Brussels, Belgium. (Series Science, $66)$.

Serviço Nacional de Levantamento e Conservação de Solos [SNLCS]. 1980. Expedite Study of the Soils of the Rio Grande do Sul and Santa Catarina States for Classification, Correlation, and Preliminary Legend = Estudo Expedito de Solos do Estado do Rio Grande do Sul e Parte de Santa Catarina para fins de Classificação, Correlação e Legenda Preliminar. SNLCS, Rio de Janeiro, RJ, Brazil. (in Portuguese).

Soil Survey Staff. 2014. Keys to Soil Taxonomy. 12ed. USDA-NRCS, Washington, DC, USA.

United States Department of Agriculture [USDA]. 1975. Soil Taxonomy: Agriculture Washington, DC, USA. (Handbook, 436).

Velasco-Molina, M.; Almeida, J.A.; Vidal-Torrado, P.; Macías, F. 2010. Chemical fractionation of carbon on Acrisols with sombric horizon from South Brazil. Revista de Ciências Agrárias 33: 277 286 (in Spanish, with abstract in English).

Volkoff, B.; Cerri, C.C. 1987. Carbon isotopic fractionation in subtropical Brazilian grassland soils: comparison with tropical forest soils. Plant Soil 102: 27-31.

Wambecke, A.R. van. 1992. Soils of the Tropics: Properties and Appraisal. McGraw-Hill, New York, NY, USA. 